\title{
Fat dads must not be blamed for their children's health problems
}

\author{
Gudrun E Moore ${ }^{1^{*}}$ and Philip Stanier ${ }^{2}$
}

Please see related research article here http://www.biomedcentral.com/1741-7015/11/29

\begin{abstract}
The relationship between the parental genomes in terms of the future growth and development of their offspring is not critical. For the majority of the genome the tissue-specific gene expression and epigenetic status is shared between the parents equally, with both alleles contributing without parental bias. For a very small number of genes the rules change and control of expression is restricted to a specific, parentally derived allele, a phenomenon known as genomic imprinting. The insulin-like growth factor 2 (Igf2/IGF2) is a robustly imprinted gene, important for fetal growth in both mice and humans. In utero IGF2 exhibits paternal expression, which is controlled by several mechanisms, including the maternally expressing untranslated H19 gene. In the study by Soubry et al., a correlation is drawn between the IGF2 methylation status in fetal cord blood leucocytes, and the obesity status of the father from whom the active IGF2 allele is derived through his sperm. These data imply that paternal obesity affects the normal IGF2 methylation in the sperm and this in turn alters the expression of IGF2 in the baby.
\end{abstract}

Keywords: Insulin-like growth factor 2, paternal obesity, DNA methylation, genomic imprinting

\section{Background}

The "parental conflict hypothesis" is the most widely accepted explanation for genomic imprinting [1]. This hypothesis is based on the conflicting interests of the maternal and paternal genomes during the offspring's growth and development. The paternal genes are directed towards the growth and fitness of the fetus, enhancing the

\footnotetext{
* Correspondence: gudrun.moore@ucl.ac.uk

${ }^{1}$ Clinical and Molecular Genetics Unit, UCL Institute of Child Health, 30 Guilford Street, London, WC1N 1EH, UK

Full list of author information is available at the end of the article
}

chances of his genome to be passed on to successive generations. The maternal genome attempts to limit fetal growth in order to distribute equal resources to each member of her litter, while ensuring her own survival during birthing to be able to reproduce again. Studies of imprinted genes generally support this model, with one of the most striking examples being the mouse insulin-like growth factor II (Igf2) [2,3] and its chelating insulin-like growth factor II receptor (Igf2r), which show reciprocal imprinting effects and associated growth patterns [4]. IGF2 is an important human fetal growth promoter that is regulated by the nearby $H 19$ gene, which is also oppositely imprinted in humans [5,6]. For a handful of these imprinted, haploinsufficient and fetally expressing genes, including IGF2, their transcription is potentially more vulnerable. Alterations in their regulation through either mutation or disturbed epigenetic processes may lead to functional abnormalities and disease states.

\section{Methylation variation and the link to functional expression}

Good examples of epigenetic syndromes are the rare imprinted human growth disorders Beckwith-Wiedemann syndrome (BWS) and Silver-Russell syndrome (SRS), where IGF2 and $H 19$ methylation are mechanistically implicated and are considered to be functionally important [7]. It now seems evident that disruption to epigenetic marks, such as DNA methylation or histone modifications, can affect the structure of chromatin and, therefore, the binding of transcription factors and other regulatory proteins [8]. DNA methylation is relatively easy to study from stored DNA samples and generally involves making comparative assessment of the methylation variation at $\mathrm{CpG}$ islands, promoters or differentially methylated regions (DMRs) between control and experimental groups of subjects. Importantly, there are both tissue- and age-specific methylation profiles and for many such marks, there is a high level of intra- and inter-individual variation that appears to have no phenotypic consequence. Caution
C Biomed Central 
must, therefore, be employed when analyzing these data. It is clear that more detailed and carefully controlled studies will be necessary to gain a complete understanding of key methylated marks and their variation relevance to development and disease [9].

\section{IGF2 expression in fetal samples and links to growth}

There have been many studies investigating the effect of human placental expression of IGF2 and its receptors on fetal growth. Given the limitations of this type of study it is not surprising that they are usually confined to samples obtained at the time of birth. Unfortunately, many of these studies seem to report conflicting results. For example, in one study no correlation was reported between IGF2 expression and birth weight [10], whereas others have shown that in small for gestational age (SGA) babies' pregnancies, IGF2 expression is either increased [11], or decreased [12], including at the protein level [13]. Nevertheless, it seems likely that IGF2 should play an important role in dictating fetal growth, even though this effect may not be reliably detected in term placenta.

\section{This study and future research}

In the study by Soubry et al. [14], the authors assess the relationship between the physiological body mass index (BMI) or obesity status of the parents with the level of methylation seen for the IGF2 and H19 gene DMRs in the leucocytes from cord blood of their newborns $(n=79)$. They find an association between the father's obesity status and the loss of methylation at the DMR linked to IGF2 but not the H19 DMR. The main caveats of this study are the small numbers and the mixture of ethnicities. In addition, it has not been shown in this study whether a small change in methylation (in this case, 4 to $5 \%$ ) at a DMR has any truly functional significance at the phenotype level. The authors point to their previous finding that a 5\% loss of methylation could lead to a $10 \%$ increase in serum concentration of IGF2 [15]. While it seems feasible that this might have both short and longer term consequences for health, it has not as yet been associated with an actual change to fetal growth. The Soubry et al. [14] study, for example, found no correlation between methylation or parental obesity and birth weight. Nevertheless, this study provides the first evidence that hypo-methylation of the regulatory control region for IGF2 is influenced by increased paternal BMI and the study makes a compelling case for a larger analysis to be performed. It is surprising and counter intuitive to note that a similar effect of hypomethylation on the IGF2 DMR is seen both for paternal obesity and maternal preconceptual famine [16]. One might assume that the father's BMI was also affected by the famine.

\section{Conclusions}

Fetal growth and development in utero is complex and will involve multiple gene pathways, many of which will not be haploinsufficient or driven by one parental allele. It is important and of particular human interest to allude to the differing roles of the parents in the developmental outcome of the future offspring. Without even considering imprinted genes, it is obvious that the two parents must have different physiological roles in pregnancy. We must consider the whole genome/epigenome/metabolome in an unbiased way, involving all key genes and networks. It is also important to critically assess environmental players. It is tempting to overemphasize the role of a small number of parent-of-origin expressing genes and to speculate about the effects of modest variation in methylation, but we must not be too hasty to blame either parent for their offspring's health outcomes without being certain that these effects are consequentially robust.

\section{Abbreviations}

BMI: Body Mass Index; BWS: Beckwith-Wiedemann syndrome; DMR: Differentially methylated region; Igf2r: Insulin-like growth factor-2 receptor; Igf2/IGF2: Mouse/Human Insulin-like growth factor-2; SGA: Small for Gestational Age; SRS: Silver-Russell syndrome

\section{Authors' contributions}

GEM and PS both contributed to drafting and editing of the manuscript and both read and approved the final manuscript.

\section{Authors' information}

GEM and PS have a specialist interest in human fetal growth and development with a view to understanding pregnancy complications. GEM was awarded an Honorary Fellowship of the Royal College of Paediatrics and Child Health in 2012 and is the Co-Director the Baby Bio Bank (http://www. ucl.ac.uk/babybiobank).

\section{Competing interests}

The authors declare that they have no competing interests.

\section{Acknowledgements}

GEM's Fetal Development and Growth Research Group is supported by the Wellcome Trust, MRC, WellBeing of Women and Sparks. PS is supported by the Great Ormond Street Children's Charity and CLEFT.

\section{Author details}

${ }^{1}$ Clinical and Molecular Genetics Unit, UCL Institute of Child Health, 30 Guilford Street, London, WC1N 1EH, UK. ${ }^{2}$ Neural Development Unit, UCL Institute of Child Health, 30 Guilford Street, London, WC1N 1EH, UK.

Received: 29 January 2013 Accepted: 6 February 2013

Published: 6 February 2013

\section{References}

1. Moore T, Haig D: Genomic imprinting in mammalian development: a parental tug-of-war. Trends Genet 1991, 7:45-49.

2. DeChiara TM, Robertson EJ, Efstratiadis A: Parental imprinting of the mouse insulin-like growth factor II gene. Cell 1991, 64:849-859.

3. DeChiara TM, Efstratiadis A, Robertson EJ: A growth-deficiency phenotype in heterozygous mice carrying an insulin-like growth factor II gene disrupted by targeting. Nature 1990, 345:78-80. 
4. Wang Z, Fung MR, Barlow DP, Wagner EF: Regulation of embryonic growth and lysosomal targeting by the imprinted lgf2/Mpr gene. Nature 1994, 372:464-467.

5. Giannoukakis N, Deal C, Paquette J, Goodyer CG, Polychronakos C: Parental genomic imprinting of the human IGF2 gene. Nat Genet 1993, 4:98-101.

6. Rachmilewitz J, Goshen R, Ariel I, Schneider T, de Groot N, Hochberg A: Parental imprinting of the human H19 gene. FEBS Lett 1992, 309:25-28.

7. Ishida M, Moore GE: The role of Imprinted genes in humans. Mol Aspects Med 2012.

8. Cedar $\mathrm{H}$, Bergman $\mathrm{Y}$ : Linking DNA methylation and histone modification: patterns and paradigms. Nat Rev Genet 2009, 10:295-304.

9. Hogg K, Price EM, Hanna CW, Robinson WP: Prenatal and perinatal environmental influences on the human fetal and placental epigenome. Clin Pharmacol Ther 2012, 92:716-726.

10. Apostolidou S, Abu-Amero S, O'Donoghue K, Frost J, Olafsdottir O, Chavele KM, Whittaker JC, Loughna P, Stanier P, Moore GE: Elevated placental expression of the imprinted PHLDA2 gene is associated with low birth weight. J Mol Med (Berl) 2007, 85:379-387.

11. Abu-Amero SN, Ali Z, Bennett P, Vaughan Jl, Moore GE: Expression of the insulin-like growth factors and their receptors in term placentas: a comparison between normal and IUGR births. Mol Reprod Dev 1998, 49:229-235.

12. Koukoura O, Sifakis S, Soufla G, Zaravinos A, Apostilidou S, Jones A, Widschwendter M, Spandidos DA: Loss of imprinting and aberrant methylation of IGF2 in placentas from pregnancies complicated with fetal growth restriction. Int J Mol Med 2011, 28:481-487.

13. Klauwer D, Blum WF, Hanitsch S, Rasher W, Lee PD, Kiess W: IGF-I, IGF-II, free IGF-I and IGFBP-1, -2 and -3 levels in venous cord blood: relationship to birthweight, length and gestational age in healthy newborns. Acta Paediatr 1997, 86:826-833.

14. Soubry A, Schildkraut JM, Murtha A, Wang F, Huang Z, Bernal A, Kurtzberg J, Jirtle RL, Murphy SK, Hoyo C: Paternal obesity is associated with IGF2 hypomethylation in newborns: results from a Newborn Epigenetics Study (NEST) cohort. BMC Med 2013, 11:XXXX.

15. Hoyo C, Fortner K, Murtha AP, Schildkraut JM, Soubry A, DemarkWahnefried W, Jirtle RL, Kurtzberg J, Forman MR, Overcash F, Huang Z, Murphy SK: Association of cord blood methylation fractions at imprinted insulin-like growth factor 2 (IGF2), plasma IGF2, and birth weight. Cancer Causes Control 2012, 23:635-645.

16. Heijmans BT, Tobi EW, Stein AD, Putter H, Blauw GJ, Susser ES, Slagboom PE, Lumey LH: Persistent epigenetic differences associated with prenatal exposure to famine in humans. Proc Natl Acad Sci USA 2008, 105:17046-17049.

Pre-publication history

The pre-publication history for this paper can be accessed here: http://www.biomedcentral.com/1741-7015/11/30/prepub

doi:10.1186/1741-7015-11-30

Cite this article as: Moore and Stanier: Fat dads must not be blamed for their children's health problems. BMC Medicine 2013 11:30.

\section{Submit your next manuscript to BioMed Central and take full advantage of:}

- Convenient online submission

- Thorough peer review

- No space constraints or color figure charges

- Immediate publication on acceptance

- Inclusion in PubMed, CAS, Scopus and Google Scholar

- Research which is freely available for redistribution

Submit your manuscript at www.biomedcentral.com/submit
Biomed Central 